\title{
BEAUTY, PRODUCTIVITY AND \\ DISCRIMINATION: LAWYERS' \\ LOOKS AND LUCRE
}

Jeff E. Biddle

Daniel S. Hamermesh

Working Paper 5366

\section{NATIONAL BUREAU OF ECONOMIC RESEARCH 1050 Massachusetts Avenue \\ Cambridge, MA 02138 \\ November 1995}

We thank the faculty member at Law School $X$ who provided the data and offered many helpful suggestions; the many people involved in rating photographs; and the LSX staff who merged the ratings with the underlying surveys. We also thank Zvi Eckstein, Frances Hamermesh, Judith Langlois, Marjorie McElroy, Edward Montgomery and participants at seminars at several universities and the NBER for helpful comments. This paper is part of NBER's research program in Labor Studies. Any opinions expressed are those of the authors and not those of the National Bureau of Economic Research.

(c) 1995 by Jeff E. Biddle and Daniel S. Hamermesh. All rights reserved. Short sections of text, not to exceed two paragraphs, may be quoted without explicit permission provided that full credit, including 1 notice, is given to the source. 


\title{
BEAUTY, PRODUCTIVITY AND DISCRIMINATION: LAWYERS' LOOKS AND LUCRE
}

\begin{abstract}
We propose several models in which an ascriptive characteristic generates earnings differentials and is sorted across sectors. The general approach shows how to distinguish the ultimate sources of labor-market returns to such characteristics; the specific example uses longitudinal data on a large sample of attorneys who graduated from one law school. Beauty is measured by ratings of their matriculation photographs. 1) Better-looking attorneys who graduated in the 1970s earned more after 5 years of practice than their worse-looking classmates, other things equal, an effect that grew even larger by the fifteenth year of practice. There is no impact of beauty on earnings among 1980s graduates. 2) Attorneys in the private sector are better-looking than those in the public sector, with the differences rising as workers sort across sector based on their beauty. 3) Male attorneys' probability of attaining an early partnership rises with beauty. The results support a theory of dynamic sorting and the role of customer behavior. We cannot determine whether this is because clients discriminate or because better-looking lawyers are able to obtain greater pecuniary gains for their clients.
\end{abstract}

Jeff E. Biddle

Department of Economics Michigan State University

East Lansing, MI 48824
Daniel S. Hamermesh

Department of Economics University of Texas Austin, TX 78712 and NBER 
You could legislate for every kind of discrimination but not this. In everything from jobs to sex the attractive were advantaged, the very plain denigrated and rejected. (James, 1995)

\section{Introduction}

Most of the immense empirical literature on discrimination in labor markets has been concerned with the task of measuring earnings gaps (if any) among workers belonging to groups defined on the basis of ascriptive characteristics. This task is complicated by the need to account for differences in productivity. In many studies, especially those concentrating on broadly-defined groups of workers and based on widely-available household surveys, the measures of productivity are disappointingly few given the heterogeneity of the respondents' occupations. Only a handful of studies (e.g., Kahn, 1992) make use of data that are sufficiently detailed to allow the authors to claim that they have purged measured earnings differentials of productivity effects. Having made the measurements, however, empirical studies seldom take the next step of attempting to determine what supports the differentials, although the theoretical literature on discrimination offers a number of possible explanations. ${ }^{1}$ There is, then, something of a gap between the theoretical and empirical literatures on labor-market discrimination, one that should be filled if we wish to target policies at those agents who are the sources of any measured labor-market discrimination rather than merely its proximate causes.

In this study we attempt to bridge that gap while exploring the economic impact of a particular ascriptive characteristic -- beauty -- that has received almost no attention from economists. ${ }^{2}$ Using a rich set of data describing a relatively homogeneous group of workers -- graduates of a particular law school -- we measure the earnings differential associated with differences in physical attractiveness and then test several hypotheses concerning alternative possible sources of the differential. In the next section we discuss alternative explanations of wage differentials among 
workers with different ascriptive characteristics and present a strategy for distinguishing among them empirically. Section III describes the data used in this study and our method of measuring the characteristic "beauty," while Section IV presents evidence of a relationship between beauty and earnings among attorneys. Section V studies how beauty affects other labor market outcomes for lawyers in an attempt to discover the sources of the beauty/earnings relationship reported in Section IV.

\section{Ascriptive Characteristics, Earnings and Occupational Sorting}

Most models of earnings that study the impact of differences in ascriptive characteristics carry with them, usually implicitly, the notion that the size of the impact will differ across sectors of the economy, leading to a sorting of workers related to the characteristic. In models of employer discrimination, for example, the earnings differentials generated by employers' reactions to a characteristic are not expected to emerge among the self-employed, although sorting may drive down their average earnings. Beckerian "taste for discrimination" models also predict greater earnings differences in regulated or monopolized sectors.

Explanations of earnings differentials based on consumer discrimination or unobserved productivity linked to the ascriptive characteristic likewise predict sectoral differences in outcomes associated with the characteristic. Some of the issues can be discussed with the help of a simple model. Assume that there are two sectors in the economy, A and B. Wages of worker $\mathrm{i}$ in each sector are given by:

$$
\begin{aligned}
& W_{A i}=a_{1} X_{1 i}+a_{2} X_{2 i}+a_{3} X_{3 i} \\
& W_{B i}=b_{1} X_{1 i}+b_{2} X_{2 i}+b_{3} X_{3 i}
\end{aligned}
$$


$X_{1}$ and $X_{2}$ are characteristics that are known to be related to productivity. $X_{3}$ is an ascriptive characteristic, which, in keeping with the focus of the subsequent empirical work, we shall call "beauty." All three are uniformly and independently distributed across workers and range between zero and one. Workers choose the sector with the higher wage. Assume that $a_{3}>b_{3}$, that is, beauty is more highly rewarded in Sector A than in Sector B, and that the other parameters are such that there are workers in both sectors. ${ }^{3}$ Under these circumstances workers of all levels of beauty are found in each sector, but the average level of beauty is higher in Sector A.

It is interesting to consider some simple modifications of the above set-up that lead to dynamic sorting, the systematic movement of workers from one sector to another as their careers progress, and that can be tested using longitudinal data. One obvious change would allow the relative returns to characteristics to change as the worker acquires labor-market experience. A change in the relative return to $\mathrm{X}_{3}$ would lead to one-way sector switching; for example, if the return to beauty rose faster in A than in B, the more beautiful B workers would switch into A, but no one would switch from $A$ to $B$.

Two-way switching requires changes in the relative returns to two of the characteristics. Thus, for example, if the return to $X_{1}$ falls in Sector A relative to the return to beauty, we would observe those more beautiful people in Sector B who are poorly endowed with $X_{1}$ switching to Sector A, while the marginally good-looking worker in Sector A who has a lot of characteristic $\mathrm{X}_{1}$ will switch to Sector B. Interestingly, it is possible for two-way switching that is systematically related to $\mathrm{X}_{3}$ to result from changes only in the relative returns to the other two characteristics. If the return to $X_{1}$ in $B$ increases while the return to $X_{2}$ in $A$ increases, under most circumstances workers will leave both sectors, with those who move from A to B being less attractive on average 
than those who stay in A. Those who move from B to A will be more attractive on average than those who remain in $\mathrm{B}$.

The general point is that in Sector A, where looks receive a relatively higher reward, the less attractive workers are on average more "marginal," i.e., they receive lower sector-specific rents. They are thus more likely to switch sectors in response to a relative increase in the return to any characteristic in Sector B. Likewise, the more attractive workers in Sector B tend to be more marginally attached there and thus more easily attracted into Sector A by favorable movements in the relative return in Sector A to another characteristic they possess.

Two-way switching also results if a very simple learning/job shopping component is added to the model (Johnson, 1978). Modify wage equations (1) by adding the sector-specific ability variables $\theta_{\mathrm{Ai}}$ and $\theta_{\mathrm{Bi}}$ to $\mathrm{W}_{\mathrm{Ai}}$ and $\mathrm{W}_{\mathrm{Bi}}$. Assume that the $\theta$ 's have zero means, are normally distributed across the population and are uncorrelated with one another and the X's. Further assume that they are unknown to employers and workers at the point of entry into the labor market, but that $\theta_{\mathrm{ji}}$ can be revealed by working in sector $\mathrm{j}$ for one period. Workers live two periods and may switch sectors at the end of period one. The values of the other parameters in (1) are known and unchanging.

A worker who chooses to start in Sector A will switch to Sector B if $W_{A i}+\theta_{A i}<W_{B i}$. Under our assumptions this switch is less likely to occur the higher is the worker's value of $\mathrm{X}_{3}$. Similarly, among workers who begin in $\mathrm{B}$ those with more $\mathrm{X}_{3}$ are more likely to make the switch to $\mathrm{A}$. Ignoring discounting, the expected value of a career begun in $\mathrm{A}$ is given by:

$$
V_{A}=W_{A}+W_{B} G\left(W_{B}-W_{A}\right)+\int_{W_{B}-W_{A}}^{\infty}\left[W_{A}+\theta_{A}\right] g\left(\theta_{A}\right) d \theta_{A}
$$

and the expected value of starting in B by: 


$$
V_{B}=W_{B}+W_{A} H\left(W_{A}-W_{B}\right)+\int_{W_{A}-W_{B}}^{\infty}\left[W_{B}+\theta_{B}\right] h\left(\theta_{B}\right) d \theta_{B},
$$

where $\mathrm{G}(\bullet)$ and $\mathrm{H}(\bullet)$ are the cumulative distribution functions of $\theta_{\mathrm{A}}$ and $\theta_{\mathrm{B}}$, and $\mathrm{g}(\bullet)$ and $\mathrm{h}(\bullet)$ are the corresponding density functions. Workers start their careers in Sector $A$ if $V_{A}>V_{B}$. Differentiation of $V_{A}-V_{B}$ with respect to $X_{3}$ shows that, other things equal, those with higher values of $X_{3}$ are more likely to choose $\mathrm{A}$ as their first sector. If $\mathrm{X}_{3}$ is attractiveness, then among junior workers the more attractive are likely to start in A. As workers learn more about aspects of their productivity unrelated to attractiveness, the less attractive will be more likely to switch to $\mathrm{B}$, while the more attractive $\mathrm{B}$ workers are the ones more likely to switch to A. Again, this result hinges on the fact that the less attractive workers are more likely to be marginal in A, while the more attractive are marginal in B.

As an empirical matter the identity of Sector $\mathrm{A}$, where $\mathrm{X}_{3}$ is more highly rewarded, depends on one's hypothesis about the source of the return to $X_{3}$. A belief that the differential arises from a general taste by employers for discrimination, as mentioned above, suggests treating self-employment as a separate sector; a preference-based theory of consumer discrimination suggests that occupations involving direct contact with consumers will offer a higher return to $\mathrm{X}_{3}$; a hypothesis of statistical discrimination implies that we are less likely to observe a return to the characteristic in sectors where productivity is easily measured and the costs of turnover are low; and so on. Once the sectoral divisions implied by a hypothesis are implemented with a particular set of data, testing involves examining differences across sectors in the returns to the characteristic, in its average levels, and in the patterns of intersectoral mobility.

Our empirical analysis is concerned with beauty (the measurement of which we discuss in the next section) and its effects on the earnings and career choices of attorneys. We consider three 
possible hypotheses about why beauty might earn a return in this labor market. First, other things equal, those who hire and promote lawyers may prefer to be surrounded by better-looking colleagues and subordinates. Second, there may be true consumer discrimination, with consumers (clients) preferring better-looking lawyers solely because of the enjoyment of spending time with them, even though their looks do not produce better settlements or judgments. Finally, consumers (clients) may prefer better-looking lawyers because their beauty is itself productive for the consumer. The socialpsychological evidence shows (see the studies cited by Hatfield and Sprecher, 1986, pp. 82-95) that people find more attractive communicators more persuasive than unattractive ones. An attorney who is more able to persuade and convince others, particularly judges and juries, may be producing higherquality legal services.

To test for employer discrimination we look for differences between self-employed lawyers and those who are employed by others. To test for the possibility that consumer behavior underlies the labor-market outcomes we divide attorneys into those in practicing in the private sector and those in all other types of practice. This division is based on the observation that the duties of a lawyer in the private sector often include a marketing component. The success of a law firm depends on its ability to attract new clients and to keep existing ones, with responsibility for this falling more heavily on the more senior lawyers or partners. A firm deciding to hire or promote a junior attorney will keep this in mind (cf. O'Flaherty and Siow, 1995, and Landers et al, 1996). If, other things equal, attractiveness gives a lawyer an edge in marketing to new clients and schmoozing with old ones, and if clients prefer to associate with attractive lawyers, then these latter will generate greater earnings for themselves and their firms. In the public sector, on the other hand, the ability to market one's services to clients is unnecessary -- the clientele is "captive" and there is no profit motive. Attorneys 
certainly do not have to worry about attracting clients to maintain their earnings. Thus if consumers' choices of lawyers lie behind a beauty effect in lawyers' earnings, the effect should be larger for attorneys in the private sector, and private-sector attorneys should be more attractive than their public-sector counterparts.

Assuming that we find such differences, it remains to determine whether consumers are basing their decisions on the ascriptive characteristic because they believe it will be productive for them or because they simply prefer it regardless of any monetary gain it might produce. If the former is true, we may infer that in our example the returns to this characteristic comes from better-looking attorneys' greater ability to win monetary or other settlements from judges, juries and other attorneys rather than from consumers indulging their own taste for discrimination. To study this ultimate question we divide the sample by legal specialization and examine how averages of their beauty differ by specialty within the private sector.

\section{Data on Lawyers and Their Looks}

Law School X (hereafter LSX) is a highly selective institution that has typically matriculated and graduated between 300 and 400 students each year. For many years it has conducted follow-up surveys of its students five and fifteen years after graduation. The faculty member in charge of this survey has also arranged to have information from the school's records merged with information from the questionnaire. For earlier cohorts of graduates this process provides a record of their scholarly and professional careers from the bachelor's degree through Year 15 of legal practice. For more recent cohorts a complete record is provided through Year 5 of practice.

LSX also typically publishes a book of photographs (usually head-and-shoulders pictures) of matriculants in each entering class. While books are no longer extant for all classes, we were able 
to obtain them for the matriculant classes from 1969-1974 (who graduated from 1971 to 1978), and from 1979-1984 (who graduated from 1981 to 1988). These photographs, provided by the students themselves, underlie the ratings of beauty that provide one of the central bases of this study. Each photograph was copied and mounted on a separate sheet of paper (to prevent contamination from faces nearby on the page) and was rated independently by four different observers: A male under 35 , a female under 35 , a male 35 or older, and a female 35 or older. Each entering class was rated by a different panel of four.

The raters were asked to place each photograph on the scale: "5, strikingly handsome or beautiful; 4 , above-average attractiveness; 3 , average; 2 , plain, below average in attractiveness; or 1, homely, far below average in attractiveness." Because the photos were examined in 1994, although some were as much as 25 years old, the raters were instructed "to make allowances for the fact that styles and fashions may have changed" and were also told for a person with "a particularly unflattering facial expression, try to imagine how they would look under ordinary circumstances." Ratings were obtained for over 4400 matriculants.

The ideal measure of beauty would account for all of a person's features that make a visual impact on others, including physical characteristics as well as grooming and habitual facial expressions or gestures. ${ }^{5}$ A photograph captures only facial features and to some extent grooming, and captures them imperfectly, as when photos are "flattering" or "unflattering." The errors thus introduced into our beauty measure, however, are unlikely to be systematically related to any of the economic outcomes upon which we focus. Also, the use of a measure of beauty based on rating photographs has one important advantage over the interviewer rating measure in the data used by 
Hamermesh and Biddle (1994), for the rater's assessment of attractiveness cannot be contaminated by other information about the subject (e.g. socioeconomic status).

The notion that beauty can systematically affect economic outcomes is predicated on the assumption that there are common standards of beauty in the population. Such standards would be reflected in a positive correlation between different raters' assessments of the same subject. The top half of Table 1 shows average pairwise correlations of around 0.40 between panel members' ratings of the matriculants who responded to the Year 5 and Year 15 surveys. Cronbach's $\alpha$ for the ratings of a four-person panel was typically 0.75 in these classes. ${ }^{6}$ This is somewhat lower than the extent of agreement in ratings of looks reported for more heterogeneous samples (Zebrowitz et al, 1993), but it still suggests substantial agreement among the raters about the appearance of the matriculants. ${ }^{7}$ That such agreement exists should hardly surprise well-read economists: Were no agreement about beauty possible, Keynes' (1936, Chapter 12) metaphor likening choosing shares of stock to, "... newspaper competitions in which the competitors have to pick out the six prettiest faces from a hundred photographs, the prize being awarded to the competititor whose choice most nearly corresponds to the average preferences of the competitors as a whole...," would make no sense.

Each matriculant's ratings were averaged to create a single attractiveness measure, and this measure was standardized within each entering class to have mean zero and variance one. ${ }^{8}$ Since not all matriculants responded to the Year 5 or Year 15 surveys, the first concern is that respondents not be selected on the basis of looks. The bottom part of Table 1 presents the mean standardized beauty ratings and sample sizes for each survey separately by respondent status. Respondents in both surveys are more attractive than nonrespondents; and the difference in average attractiveness is greater in the survey at Year 15 than at Year 5, as one would expect if looks have some ultimate 
positive effect on success and success increases the probability of response. The difference in Year 5 between respondents and nonrespondents is tiny, however, and even at Year 15 it is not significant. This suggests that we need not be too concerned about sample selection in this case. ${ }^{9}$

Table 1 shows a striking result: The average attractiveness rating of male respondents is well below that of the female respondents. The difference in the average ratings of beauty is independent of the sex of the person doing the rating, and such large average differences are not observed in most of the psychology literature. While the average beauty of men in the sample was approximately the same in the two cohorts of matriculants, women in the earlier cohort were rated as substantially better-looking than their female successors (as can be seen by comparing the average ratings for women in the Year 5 and Year 15 samples). This difference across cohorts may reflect favorable treatment of beauty in the admissions process in the late 1960s (since pictures were not usually included in applications in the later cohort), and/or it may result from good-looking women's greater beliefs during the 1960s that their beauty would pay off in the legal profession. Whatever the reasons, the differences make it essential that all the analyses be performed separately by sex and cohort. Since there were very few female matriculants in the late 1960s and early 1970s at LSX, this means that some of the results are based only on male attorneys.

The LSX surveys provide large amounts of information on the respondents' backgrounds, performance and activities in law school, their career histories and their current work activities and environments. Questions have been changed, added or dropped over the years. Thus in defining the samples to be used in the analyses we traded off the desire for more information on each respondent against the loss of observations because some information was unavailable for some respondents (or 
even for entire graduating classes). Unless the loss of observations from adding another variable was very small, we generally chose to restrict the information and retain a larger sample.

In analyzing the Year 5 samples we use two sets of variables: 1) Personal, educational and first-job characteristics, a vector $\mathbf{P}_{1}$, including indicator variables for race; type of college (Ivy League or Seven Sisters; public in the state where LSX is located; other public); years of post-BA, pre-law school experience, and whether a master's or doctorate was obtained in this period; whether the person was on a law journal at LSX or argued in a moot-court competition; class rank; whether he or she held a judicial clerkship after law school; and whether the first job was in the private sector. Also included in $P_{1}$, mainly as a proxy for unmeasured quality, is the number of jobs held between graduation and Year $5 .{ }^{10}$ 2) Year 5 job characteristics, $\mathrm{J}_{5}$, including years of practice in the private sector; a vector of indicator variables for the size of the MSA where the person works; another vector for the number of other attorneys in the office $(16-50 ; 51-150 ;>150)$; and an indicator of whether the person was working in the private sector. In studying the Year 15 respondents we also include the vector $\mathrm{J}_{15}$, containing the same variables as $\mathrm{J}_{5}$ but observed at Year 15 .

The Year 5 surveys contain retrospective information on income from the first post-law school job, $\mathrm{W}_{1}$, and the current income from the principal job in Year 5, $\mathrm{W}_{3}$. From the Year 15 surveys we use income from the principal job in Year $15, \mathrm{~W}_{15}{ }^{11}$ The measures of $\mathrm{W}_{5}$ and $\mathrm{W}_{15}$ are reports of current earnings, but that of $W_{1}$ is retrospective and may contain more sampling error. That potential problem is likely, however, to be very small for this population of professional workers for whom the initial salary is probably quite salient. Each nominal wage is deflated by the Consumer Price Index for the year for which it is reported, so that all comparisons are in constant (1982-84) dollars. 
One should note throughout this discussion and in Sections IV and V that we have a sample that is remarkably homogeneous. All the matriculants performed very well as undergraduates, and all received essentially the same basic training at the same law school. Bearing that in mind, Table 2 shows the means and standard deviations of some of the major variables. The 1970 s cohorts were more likely to be working in the public sector, legal aid or nonprofit institutions in Year 5 than their 1980s counterparts, and less likely to be working in large law firms. They held significantly fewer jobs during the first five years after law school, perhaps a reflection of the rapid growth in demand for attorneys in the 1980s (see Rosen, 1992), perhaps of intercohort differences in sitzfleisch. ${ }^{12}$

Despite their observational homogeneity the samples exhibit a remarkably typical extent of underlying heterogeneity. The variance (and coefficient of variation) of earnings increases sharply between Years 5 and 15, reflecting the "fanning-out" that is observed in age-earnings profiles generally (Mincer, 1974). At Years 1 and 5 there are small but significant sex differences in earnings, a fact noted for a sample of lawyers by Wood et al (1993). Finally, like workers generally these attorneys settle into jobs as they age: Between graduation and Year 5 they hold 0.65 additional jobs (a 15 percent turnover rate per annum), but in the next 10 years on average only 0.54 additional jobs are obtained (only a 5 percent annual turnover rate).

\section{The Effect of Beauty on Earnings}

In this Section we consider whether a relationship between attractiveness and earnings exists in this market, how it differs by sex and cohort, and how it evolves over workers' careers. Tables 3 and 4 examine the earnings-beauty relationship for men and women and for each cohort separately. The estimated coefficients on the variables in the vectors $P_{1}$ and $J_{5}$ are presented in Appendix Table 1. Given the observational homogeneity of the samples these regressions account for surprisingly 
large fractions of the intrasample variance in earnings. Despite their homogeneity the plethora of information that we have on the respondents' characteristics accounts for as much of the variance in earnings as is standard in such equations describing much more heterogeneous samples (e.g., Current Population Surveys).

For both sexes the effects of attractiveness on earnings are small during the first post-law school year. Indeed, they differ little by sex or by cohort, with a two-standard-deviation increase in the standardized rating producing an insignificant increase in wages of around three percent. The estimates lead to the general inference that there is a small and weak positive relationship between beauty and initial earnings even holding constant a wide array of job and personal characteristics.

The effect of attractiveness on earnings at Year 5 is quite large for the 1970s cohort, although for (the very small sample of) female attorneys most of the effect disappears once the large vectors of controls are accounted for. Among male attorneys the estimated effect of beauty on earnings is robust to adding these vectors. In the 1970s cohort of men a two-standard deviation increase in attractiveness is associated with about a ten-percent increase in earnings. ${ }^{13}$ Least absolute distance regressions yield essentially the same inferences as the OLS estimates presented in the Table. Also, the effect does not stem from any asymmetry in the market's response to beauty: Additional tests show that the earnings penalty on attorneys in the bottom decile of beauty equals in absolute value the earnings premium for those in the top decile.

In the 1980 s cohort the effects of beauty on earnings at Year 5 are much smaller and statistically insignificant. When the controls are added they fall essentially to zero, although the estimated coefficients are never negative. Among men, moreover, the effect is significantly less than in the 1970s cohort at Year $5(t=2.35$ on the difference between the estimates in the final column of 
Table 3). This change is not part of a generalized decline in returns to the attributes that affect earnings: As a comparison of the first two columns in Appendix Table 1 shows, the impacts of most of the other variables that affected the earnings of young attorneys increased over this decade.

The sharp drop in the return to beauty at Year 5 in the later cohort is more curious in light of the results in Table 5, which presents estimates like those in the second tableau in Table 3, but for the slightly smaller sample of lawyers from the 1970 s cohort for whom all the data in the vectors $P_{1}$, $\mathrm{J}_{5}$ and $\mathrm{J}_{15}$ are available. The conclusions about Year 5 earnings in the broader sample from the $1970 \mathrm{~s}$ cohort are repeated in the estimates for this reduced sample that are presented in the top half of the Table. The bottom tableau shows the effect of beauty on earnings at Year 15. (The estimates of the coefficients on the vectors $P_{1}, J_{5}$ and $J_{15}$ are presented in Appendix Table 2.) During the same years that the 1980 s cohort received little or no return to beauty the impact of beauty on the 1970 s cohort's earnings grew. ${ }^{14}$ By the time the cohort was well established in legal practice an attorney whose appearance in a photograph taken on average nearly twenty years earlier placed him one standard deviation below the mean of looks was earning around 12 percent less per annum than one whose looks at that time put him one standard deviation above the mean.

Column (3) of the bottom tableau of Table 5 presents the same equation as column (2), but with Year 15 annual hours included as an additional characteristic. Comparing the coefficients in the two equations, we can infer that better-looking lawyers work longer hours at Year 15; but most of the impact of beauty on earnings is a pure wage effect, not simply a matter of bringing in more business at the same hourly pay. Greater beauty enabled the mid-career attorneys in this cohort to bill at a higher rate, not just to bill more hours. ${ }^{15}$ 
The absence of a significant return to beauty for the later cohort at Year 5, coupled with the substantial return to beauty in the earlier cohort at Year 15, makes it clear that beauty was not traded in an implicit spot market in the late 1980s and early 1990s. The rapid growth in demand for lawyers' services in the late Eighties might explain this, but only if its impact differed across the two cohorts. Interestingly, that appears to have been the case. Among professionals age 30-34 with advanced degrees, CPS data show that between 1979-83 and 1989-93 the wages of full-time attorneys rose relative to those of college professors by 15 percent, those of health professionals by 11 percent, those of natural scientists by 16 percent, and those of engineers by 16 percent. ${ }^{16}$ At the same time the relative earnings of attorneys age $40-44$ were 5 and 28 percent lower than those of professors and health professionals respectively in 1989-93 than in 1979-83, and only 4 and 2 percent higher than those of natural scientists and engineers, suggesting there was less excess demand for older lawyers.

In many law firms older attorneys are responsible for attracting and retaining clients, and their good looks might work to their advantage in this area. It may be that firms responded to the increase in demand for legal services mainly by hiring more young associates to produce the legal output for the growing number of clients whom the more senior attorneys were attracting. Under these circumstances the importance of young lawyers' ability to produce high-quality work under the direction of a senior attorney may have grown relative to their future ability to market the firm's services.

The difference between cohorts in the effect of beauty is also consistent with the notion that the impact of a characteristic early in the career affects its subsequent impact. This statement about the time path of the return to a characteristic as a cohort ages is similar in a complex earnings function to the observation by Baker et al (1994) that the subsequent level of wages in a firm's cohort of 
workers depends on the state of the labor market early in its career. It is also consistent with the more conventional notion (Berger, 1985) that a cohort's size affects its wages over its entire working life. A good test of the alternative explanations and analogies can regrettably only come from data available in 1996-2003 on the earnings of the 1980s cohort at Year 15 of their careers.

Taken together the findings in this Section are remarkable evidence for the role of beauty in the labor market. A skeptic might object that beauty is correlated with unobservable characteristics that produce economic success. Those same characteristics are, however, surely reflected in success in law school in the form of good grades, participation in moot-court competitions and law journals, so that it seems very likely that our law-school background measures account for this possibility. One form of possible simultaneity between earnings and beauty, caused by high-paid workers using their earnings to "buy beauty," is obviously not a problem here, as our beauty measures reflect the subjects' appearance many years before they entered the labor market. A more complex form of simultaneity might arise if earnings capacity is partly heritable and parents of highly-paid lawyers invest more in their children's looks. This is possible, but a straightforward test decisively rejects the relevance of this argument in this set of data. ${ }^{17}$

\section{Sorting and the Sources of Wage Effects}

While we have demonstrated the existence of a large and growing effect of beauty on earnings in one cohort of attorneys, the more interesting and more general question is what the evidence implies about the sources of this return. As a first step we should note that the effect of beauty on attorneys' careers may begin before the first job is entered. Thus to understand its role in a particular labor market we need to analyze its relation to some of the measures that we have found affect earnings, in this case how it relates to achievement while in law school. The first three rows of Table 
6 present the effects of a one-standard deviation increase in the standardized average beauty rating on class rank (with a higher number implying a lower overall rank), the probability of participating in a moot-court competition, and the probability of being on a law journal. None of these effects is significantly nonzero at conventional levels, though there is some weak evidence that beauty does increase female law students' chances of participating in one of the non-class activities in law school. In general, however, there is little evidence of any pre-labor market effects of beauty. Most of this is not surprising: Grading at this law school is anonymous, as is selection onto the law journals.

The final row of Table 6 relates the probability of obtaining a judicial clerkship to the standardized average beauty rating, holding constant all the variables in $P_{1}$ that were determined before the clerkship was entered.$^{18}$ In all three groups for which the probit could be estimated the impact of beauty is negative, and for the 1980 s cohort of men the effect is significantly negative. It is difficult to believe that judges negatively select their clerks based on looks. Rather, the results are consistent with better-looking new graduates believing that beauty will aid them in the labor market and being less interested than their less attractive classmates in obtaining clerkships that will postpone their reaping returns to this characteristic.

The explanations in Section II suggested the existence of distinct sectors in the labor market and predicted both differences in the returns to beauty across them and systematic sorting of workers related to their beauty. One explanation based on some form of employer discrimination implied that a beauty effect will not be found among the self-employed, since there is ipso facto no employer who can discriminate. The sample used to generate the earnings equations reported in Table 3 includes 60 male lawyers in private solo practice. We augmented the Year 5 earnings regressions for men with an indicator variable identifying these self-employed attorneys and an interaction between that 
variable and the beauty measure. A negative value of the interaction would be consistent with employer discrimination; but we find instead that this term is positive, though statistically insignificant. ${ }^{19}$ A test of the hypothesis that the sum of the coefficients on the interaction term and the main effect of beauty equals zero is rejected at the 90 percent level of confidence. Thus a comparison to the small group of self-employed lawyers in our sample provides no evidence that employer discrimination explains the effect of beauty on earnings. If anything, beauty pays off more for self-employed junior attorneys than for employees.

To begin considering the potential role of consumer discrimination or productive beauty we next divided the sample between attorneys practicing in the private or in the public sectors. (The latter includes those working for government -- prosecutors, staff attorneys for government agencies, etc.; legal-aid lawyers, and those who categorize their practice as "other," most of whom probably work for non-profit organizations.) The first panel of Table 7 shows for the 1970s classes the means of the standardized average beauty rating in each sector at Years 5 and 15. Male private-sector attomeys are more attractive on average than are male public-sector attorneys at both 5 and 15 years after graduation. Moreover, the gap between the two sectors grows over the ten years. In the very small sample of women the public-sector lawyers are more attractive at Year 5, while at Year 15 those in the private-sector are better-looking. ${ }^{20}$

To study more closely the phenomenon of two-way switching that was described by the model in Section II we divided the sample of male lawyers into four groups: Those in the public sector in Years 5 and 15 (public stayers), in the private sector in both years (private stayers), in the private sector in Year 5 but the public sector in Year 15 (private leavers), and those in the public sector in Year 5 and the private sector in Year 15 (public leavers). We estimate a multinomial logit model 
including variables describing performance in law school to discover whether the probability of membership in these groups was systematically related to beauty. The results in the second panel of Table 7 show that private stayers (the comparison group) are more attractive than public stayers. Furthermore, lawyers who left the private sector between Years 5 and 15 are less attractive than those who remained, while lawyers who switched from the public sector are more attractive than those who stayed there. ${ }^{21}$

Could differences in the returns to beauty in the two sectors explain this pattern of mobility? We examine this possibility in Table 8 , which reports results of separate earnings regressions estimated for men in the 1970s classes in private- and public-sector practices. These results may also shed light on possible employer discrimination, as public employers, shielded from competition, would have more freedom to indulge their tastes for attractive employees. In both years, but especially at Year 15, the variance in earnings among attorneys in the public sector is much lower and is reflected in the lower $\vec{R}^{2}$ in the regressions describing the public sector. Despite this, the coefficient on beauty is slightly higher in the public sector in Year 5 and lower in Year 15, though the differences are not statistically significant.

These results show equal returns to beauty in percentage terms, since the equations describe the logarithms of earnings. Average earnings are lower in the public sector, however, with the gap at Year 15 being very large. This implies that while the returns to beauty at Year 5 are roughly the same in dollar terms, by Year 15 a one standard-deviation increase in average beauty is worth $\$ 3200$ to the average public-sector attorney, but $\$ 10,200$ to the average private-sector attorney. ${ }^{22}$ This rising absolute difference in the returns to beauty provides an incentive for better-looking lawyers to change sectors, even though the difference in the percentage returns to beauty remains unchanged, 
so long as some of the costs of job-changing are fixed. At the very least it seems reasonable to argue that these costs are in part psychic and thus probably fixed, so that the behavior implied by the evidence on two-way switching is consistent with the incentives shown in these earnings regressions.

The combined evidence of Tables 7 and 8 accords with the notion that beauty is productive in private attorneys' efforts to attract and retain clients (consumers), an activity that becomes more important with experience. Additional evidence supporting this interpretation, at least for men, is presented in Table 9. It shows separately for the 1970s and 1980s cohorts the effect of an increase in standardized average beauty on the probability of the unusual event that the attorney becomes a partner in a law firm by Year 5. (Early partnerships were rare but much more frequent among 1970s graduates than among the 1980s graduates.) The estimates are derived from probits on samples limited to private-sector attorneys. Among men in both cohorts the statistically significant point estimates imply that a one standard-deviation increase in attractiveness increased the probability of early partnership by over 20 percent. The results for women, on the other hand, reveal one of the few significant differences in the effect of beauty by sex that we have found: Greater attractiveness among women lowers their chances of early partnership. ${ }^{23}$

In sum, by five years after law-school graduation attorneys have sorted themselves so that those in the private sector are better-looking than those in the public sector, a sorting that continues between Years 5 and 15 . The monetary returns to beauty are roughly equal in the two sectors at Year 5; but if we also consider the option value of location in the private sector generated because beauty raises the chances of promotion, we can perhaps explain the sectoral differences in attractiveness at Year 5. The widening gap in the dollar returns to beauty can account for the 
movement of more attractive public-sector workers to the private sector that we observe occurring between Years 5 and 15.

In the earnings regressions in Table 8 we also found that the percentage returns to being on a law journal and to a higher class rank rise in the private sector relative to the public sector, while the returns to having held a clerkship rise relatively in the public sector. ${ }^{24}$ As the model of Section II suggests, with these relative changes moving in opposite directions we would observe flows of workers of different beauty even if sectoral differences in the returns to beauty did not change over time.

The greater rewards for attractiveness in the private sector are consistent with the notion that choices by consumers (clients) help to support the return to beauty in the market for attorneys. However, as we discussed earlier, there are two conceptually distinct reasons why consumers might wish to hire more attractive attorneys. The first is the desire to indulge a taste for spending time with better-looking people; the second is a belief that better-looking attorneys will generate greater financial gains for them as a result of the discriminatory attitudes of judges, juries or adversarial parties. The two possibilities are not mutually exclusive. The latter might explain why the return to beauty in the public sector, while apparently lower than in the private sector, is still positive: Opportunities for advancement in the public sector are likely to be enhanced by greater success in front of judges and juries. The final task of this section is to search for additional evidence on the question of whether beauty is productive for attorneys.

If more attractive lawyers are more productive in the sense of being more persuasive, our model suggests that they will be disproportionately represented in legal specialties where their beauty could assist them in generating more favorable judgments for clients. The data set allow us to make 
at least a rough attempt at determining where this occurs. Graduates from classes after 1979 were asked how they spend their work time. Based on the attorney's most frequent activity, an experienced attorney used the 24 possible responses to classify the respondents into the four categories of litigation, corporate/finance, regulation/administrative, and other ${ }^{25}$ (Results based on the percent distributions of each respondent's work time differed little.) Since litigators deal with judges and juries more than do attorneys in other specialties, we would expect them to be better-looking.

The first two parts of Table 10 present average standardized beauty ratings by sex for each of the four groups of specialties chosen by attorneys from the 1980s cohort who practiced in the private sector at Year 5. For both sexes in this cohort the litigators are indeed the most attractive among the four groupings. The same interspecialty differences exist among men from the 1970s cohort at Year 15, with litigators again being better-looking than those in other specialties. The results thus accord with the productivity hypothesis (put differently, with the hypothesis that the ultimate source of the earnings advantage is with judges, juries and other lawyers who treat betterlooking advocates especially well); but none of the differences between the average beauty in any pair of specialties even approaches statistical significance.

The division of specialties into those where beauty is more or less likely to affect pecuniary outcomes of legal cases is subjective. To carry this approach one step further in an objective manner we performed an analysis of variance of the standardized average beauty ratings by sex across each of the 24 legal specialties. The p-values describing the F-statistics for these analyses were 0.22 among male attorneys and 0.54 among female attorneys at Year 5 in the 1980 s cohort. Among male attorneys at Year 15 in the 1970 s cohort the $p$-value is 0.33 . This objective classification of lawyers by specialty implies very clearly that average beauty differs little across legal specialties. We may 
conclude that our possibly crude measures of specialization generate only weak evidence that attorneys sort themselves by specialty in ways that are consistent with their believing that beauty produces more advantageous outcomes for their clients.

\section{Conclusions}

We have demonstrated how one particular ascriptive characteristic -- beauty -- is related to wages in one profession. The richness of our data has allowed us to examine longitudinal variation in the returns to beauty and to be particularly careful to avoid simultaneity problems with a characteristic that could partly be affected by income. The evidence seems very clear that beauty is not merely correlated with but actually causes differences in earnings. In the cohort of attorneys who graduated from law school in the early to mid-1970s the effect of beauty on earnings grew as they matured in their practices. The absence of any effect in the cohort of attorneys who graduated in the early and mid-1980s may stem from the temporary tightness of the legal labor market or from changes in society's attitudes about this characteristic, and it demonstrates that there is no implicit spot market for beauty.

Several possible causes of the effect on professional earnings suggest themselves, including employer discrimination, customer discrimination and discrimination by judges/juries that makes beauty productive for attorneys. The absence of greater returns to beauty among employed as compared to self-employed lawyers suggests that we can rule out employer discrimination. That the effect is generated by clients' preferring to engage better-looking attorneys is supported by the finding that the monetary return to beauty rises especially rapidly in the private sector; by the fact that more attractive men obtain partnerships early, and by attorneys switching between the public and private sectors based partly on looks. 
We cannot distinguish very well whether clients' choices result from their pure taste for discrimination or from their correct belief that judges, juries and other attorneys treat better-looking advocates more favorably, so that engaging a good-looking lawyer will generate pecuniary gains for the client. Indeed, both causes may operate. The notion that the ultimate source of the effect of beauty on earnings is a generalized preference for good looks that is diffused among all those involved in the legal system is consistent with the existence of a positive return to beauty even in the public sector; but the absence of good evidence of sorting between legal specialties based on looks points more toward pure customer discrimination.

More important than our demonstration of beauty's effect on earnings is the approach we have indicated and followed for determining the source of that impact, an approach that is relevant for the study of any ascriptive characteristic. Simply demonstrating that some characteristic generates effects in the labor market, as has become standard in studies of labor-market discrimination, is not enough. If we are concerned about those effects, we cannot assume that employers are the ultimate cause simply because they are the proximate cause. Instead, we need to determine the ultimate cause to discover whether public-policy intervention is required and, if so, how to target it efficiently and equitably so as to alter the labor-market effects of the particular characteristic.

There is a very large literature on workers' sorting themselves across fields/areas/industries depending on the relative returns to some particular characteristics that they may possess. We have extended models of that type to account for the dynamic sorting that occurs as the returns to characteristics in different submarkets change over time or as information is revealed to workers about their relative productivity in different sectors. We find empirical support for the standard implication that workers choose that type of work where the payoff to the characteristic with which 
they are relatively well endowed is the greatest; but we also generate evidence that dynamic sorting occurs in directions consistent with changes in the relative returns to the characteristic (in this case beauty). This analysis could be fruitfully applied to examining patterns of dynamic sorting by race and sex to study the impact of discrimination along those characteristics. Other areas of labor-market behavior, for example, risk-taking in occupational choice, where returns differ across sectors and change as workers age might also be examined using this approach. 


\section{REFERENCES}

George Baker, Michael Gibbs and Bengt Holmström, "The Wage Policy of a Firm," Quarterly Journal of Economics, 109 (1994): 881-920.

Mark Berger, "The Effect of Cohort Size on Earnings Growth: A Reexamination of the Evidence," Journal of Political Economy, 93 (1985): 561-73.

George Borjas and Stephen Bronars, "Consumer Discrimination and Self-Employment," Journal of Political Economy, 97 (1989): 581-605.

David Buffum and Robert Whaples, "Fear and Lathing in the Michigan Furniture Industry: Employee-Based Discrimination A Century Ago," Economic Inquiry, 32 (1995): 234-52.

John Goddeeris, "Compensating Differentials and Self-Selection: An Application to Lawyers," Journal of Political Economy, 96 (1988): 411-28.

Daniel Hamermesh and Jeff Biddle, "Beauty and the Labor Market," American Economic Review, 84 (1994): 1174-94.

Elaine Hatfield and Susan Sprecher, Mirror, Mirror. The Importance of Looks in Everyday Life. Albany: SUNY Press, 1986.

James Heckman and José Scheinkman, "The Importance of Bundling in a Gorman-Lancaster Model of Earnings," Review of Economic Studies, 54 (1987): 243-55.

P.D. James, Original Sin. New York: Knopf, 1995.

William Johnson, "A Theory of Job Shopping," Quarterly Journal of Economics, 92 (1978): 261-78.

Lawrence Kahn, "The Effects of Race on Professional Football Players' Compensation, " Industrial and Labor Relations Review, 45 (1992): 295-310.

John Maynard Keynes, The General Theory of Employment, Interest and Money. New York: Harcourt, Brace and World, 1936.

Renée Landers, James Rebitzer and Lowell Taylor, "Rat Race Redux: Adverse Selection in the Determination of Work Hours," American Economic Review, 86 (1996): forthcoming.

Judith Langlois and Lori Roggman, "Attractive Faces Are Only Average," Psychological Science, 1 (1990): 115-21.

Jacob Mincer, Schooling, Experience and Earnings. New York: National Bureau of Economic Research, 1974. 
Brendan O'Flaherty and Aloysius Siow, "Up or Out Rules in the Market for Lawyers," Journal of Labor Economics, 13 (1995): 678-708.

Sherwin Rosen, "A Note on Aggregation of Skills and Labor Quality," Lournal of Human Resources, 18 (1983): 425-31.

--ore "The Market for Lawyers," Journal of Law and Economics, 35 (1992): 215-46.

Stephen Spurr and Glenn Sueyoshi, "Turnover and the Promotion of Lawyers," Journal of Human Resources, 29 (1994): 813-42.

Robert Wood, Mary Corcoran and Paul Courant, "Pay Differences among the Highly Paid: The Male-Female Earnings Gap in Lawyers' Salaries," Journal of Labor Economics, 11 (1993): 417-41.

Leslie Zebrowitz, Joann Montepare and Hoon Koo Lee, "They Don't All Look Alike: Individuated Impressions of Other Racial Groups," Journal of Personality and Social Psychology, 65 (1993): 85101. 


\section{FOOTNOTES}

1. Some authors, such as Borjas and Bronars (1989) and Buffum and Whipple (1995), concentrate on measuring one particular form of discrimination (by consumers and by fellow employees, respectively).

2. The relationship between beauty and economic success has, however, received substantial attention from the news media. See, for example, New York Times, March 22, 1994, p. A6, or ABC's 20/20, November 4, 1994.

3. Differences across sectors in the returns to the same characteristic in a competitive equilibrium are discussed by Rosen (1983) and Heckman and Scheinkman (1987). Only under very restrictive assumptions on how characteristics enter the sector-specific production functions will one observe equalization of returns across sectors.

4. If we assume instead that $X_{3}$ is a dichotomous characteristic, it is possible to have workers of both types in both sectors, with the majority of the high $\mathrm{X}_{3}$ workers in Sector $\mathrm{A}$. Adding more sectors and characteristics to the model does not change the basic conclusion that workers will sort into sectors that pay a greater reward to the attributes they possess.

5. Langlois and Roggman (1990) discuss the psychology of perceptions of beauty.

6. For two of the twelve years only two raters were used. As in the other cases an average rating was formed from this reduced number of constituents.

7. Current unfamiliarity with styles of dress from the late 1960 s could have led to greater heterogeneity in the ratings of members of the early cohort. In fact, however, Cronbach's $\alpha$ and the average pairwise correlations among the raters were both slightly higher for the earlier cohort.

8. Under the assumption that each class represents a sample drawn from the same population with respect to attractiveness, the standardization controls for differences across rating panels in "generosity."

9. This result also holds if we disaggregate respondents and nonrespondents by sex: The differences in average beauty are independent of respondent status among both men and women.

10. Excluding this last measure has virtually no impact on any of the estimates of the effects of beauty on earnings. Similarly, only tiny changes are produced if we add yet another measure of ability to the equations, a composite of the matriculant's adjusted undergraduate GPA and LSAT score.

11. Both $W_{5}$ and $W_{15}$ are based on answers to questions about "net (pre-tax) earnings" from the "principal position."

12. This differs from Spurr and Sueyoshi's (1994) finding of little difference across these cohorts in turnover rates among a group of lawyers with more heterogeneous backgrounds.

13. By a standard errors-in-variables argument we can conclude that, if we had used more raters for each photograph, the estimated impact of standardized beauty would probably have been larger.

14. If we include only $W_{5}$ and the vector $J_{15}$ in an equation relating $W_{15}$ to beauty, we again find that the returns to beauty in this cohort increased as it aged. 
15. Data on annual hours worked are not available in the Year 5 surveys for classes that graduated before 1976 , so that we cannot examine this equation for the 1970s cohort in Year 5. For men (women) in the 1980s cohort reestimating the final equation in Table 3 (Table 4) does not alter the conclusion about the insignificant impact of beauty at Year 5 .

16. The calculations are based on the usual weekly earnings of all full-time workers in these occupations who had at least 18 years of schooling (after 1991, more than an M.A.) from the 1979-1993 Outgoing Rotation Groups of the Current Population Survey.

17. We added to the earnings regressions a measure of the fraction of law-school costs that were defrayed by the student's parents. Including this proxy for parental wealth had essentially no impact on the coefficients of the beauty measure.

18. Not surprisingly, being on a law journal and class rank have significant effects on the probability of attaining a clerkship. None of the other variables in $\mathrm{P}_{1}$ has any noticeable impact. The probit was not estimated for the 1970s cohort of women, because only 3 of the 82 respondents obtained clerkships.

19. The main effect of beauty had a coefficient of 0.025 (s.e. of 0.008 ), the coefficient on the main effect of solo practice was -0.033 (s.e. of 0.040 ), and the coefficient on their interaction was 0.034 (s.e. of 0.037 ).

20. The average attractiveness of all attorneys in this subsample rose between Years 5 and 15 because those who left the practice of law during this interval were significantly less attractive than those who continued to practice. As the dynamic sorting model of Section II shows, this could result from the rising return to attractiveness with experience in the legal profession noted in Section III accompanied by a decline in the relative returns to other characteristics.

21. Caroline Minter-Hoxby observed that this result could be an artifact of low beauty ratings having been assigned to men who were poorly dressed for their pictures and who also had a preference for public-sector jobs, with well-dressed men being rated higher and preferring private-sector jobs. It is true that the average beauty rating was significantly lower among the 30 percent of men in the 1970 s cohort who did not wear a tie in their photograph. However, the distributions of attorneys in the four categories listed in the upper left of Table 7 were remarkably similar among the better- and the worse-dressed groups. (83 percent of the former, 81 percent of the latter were in the private sector in both years.) Moreover, if we limit the sample to those who wore ties, the standardized average beauty ratings in the four sectoral categories in Table 7 were .096 , $.093,-.429$ and -.021 -- somewhat stronger support for our hypothesis than is provided by the full sample. As an additional check, in the regressions in Part B of Table 3 the variable "NOTIE" had absolutely no effect on the impact of standardized beauty on earnings.

22. Whether the average public-sector worker could expect to see both his salary and the return to his attractiveness rise following a move to the private sector depends on the extent to which salary differences across the sectors represent a compensating differential or instead reflect sectoral differences in productivity induced by self-selection (Goddeeris, 1988). Our earnings regressions, which include detailed controls for productivity, still indicate a 25 percent shortfall in the earnings of public-sector attorneys by Year 15 . (Notice that this difference is far below the raw earnings difference -- 158 percent -- between attorneys in the two sectors at Year 15.) Also, holding constant Year 5 earnings, lawyers who switched from the public sector earned considerably more in Year 15 than those who stayed, while those who left the private sector earned much less than those who stayed there. This suggests very strongly that the average public-sector lawyer who switched to the private sector in Year 15 would experience a substantial earnings gain. 
23. Adding marital status and the presence of children at the time of law-school graduation to these probits does not qualitatively affect the conclusions. However, more attractive female attorneys were also more likely to be married at Year 5, while attractiveness did not significantly affect male attorneys' probability of being married.

24. The growing returns are presumably due to skills that enabled the person to qualify for the law journal or achieve a higher class rank, not to those achievements per se.

25. Respondents who stated that their practice was mainly debtor/creditor, civil rights, criminal law, domestic relations, or torts and personal injuries were classed as being mainly in litigation. Those who listed themselves as being in antitrust, corporate, employee benefits, estates, or securities law were classified as corporate/finance; attorneys whose specialties were banking, communications, energy, environmental, or immigration law were classified as in regulation/administrative law. Those in other specialties were included in the catch-all category "other." 
Table 1. Description of Ratings of Beauty

$\begin{array}{ccc}\text { Average Pairwise Correlation, } \\ \text { Graduates Used in Analysis } \\ \text { Year } 5 \text { Sample } & \text { Women } \\ & \begin{array}{c}0.405 \\ (1567)\end{array} & 0.398 \\ \text { Year } 15 \text { Sample } & (401) \\ & 0.446 & \\ (623) & \end{array}$

All Matriculants: Mean stdzd. Rating

Year 5 Year 15

Sample Sample

Respondents :

$0.0088 \quad 0.0224$

(2469) (1245)

Men

$-0.0455-0.0254$

(1903) (1097)

$\begin{array}{lll}\text { Women } & 0.2046 & 0.3769\end{array}$

(566) (148)

Nonrespondents $\quad-0.0115 \quad-0.0287$

(1917) (971)

${ }^{2}$ Number of observations in parentheses. 
Table 2. Means (and S.D.) of Important Variables

\begin{tabular}{|c|c|c|c|c|c|}
\hline & \multicolumn{4}{|c|}{ Year 5 Sample } & \multirow{2}{*}{$\begin{array}{c}\text { Year } 15 \text { Sample } \\
\text { Men, Classes } \\
\text { from 1970s }\end{array}$} \\
\hline & $\begin{array}{c}\text { Men, Class } \\
1970 \mathrm{~s}\end{array}$ & $\begin{array}{l}1980 \mathrm{~s} \\
\text { 19es from }\end{array}$ & $\begin{array}{l}\text { Women, } \\
1970 \mathrm{~s}\end{array}$ & $\begin{array}{c}\text { Classes from } \\
1980 \mathrm{~s}\end{array}$ & \\
\hline \multicolumn{6}{|l|}{$\begin{array}{l}\text { Real Wage: } \\
\quad(1982-84 \$)\end{array}$} \\
\hline Year 1 & $\begin{array}{l}\$ 29,124 \\
(8,055)\end{array}$ & $\begin{array}{l}\$ 34,287 \\
(10,588)\end{array}$ & $\begin{array}{l}\$ 27,877 \\
(7,367)\end{array}$ & $\begin{array}{l}\$ 33,834 \\
(10,949)\end{array}$ & $\begin{array}{l}\$ 29,056 \\
(8,125)\end{array}$ \\
\hline Year 5 & $\begin{array}{l}\$ 46,859 \\
(14,830)\end{array}$ & $\begin{array}{l}\$ 52,053 \\
(19,594)\end{array}$ & $\begin{array}{l}\$ 44,541 \\
(17,879)\end{array}$ & $\begin{array}{l}\$ 47,782 \\
(18,475)\end{array}$ & $\begin{array}{l}\$ 46,214 \\
(13,390)\end{array}$ \\
\hline Year 15 & --- & --- & --- & --- & $\begin{array}{l}\$ 116,965 \\
(82,374)\end{array}$ \\
\hline Class rank & 175.04 & 167.63 & 188.74 & 186.74 & 175.4 \\
\hline Law journal & 0.219 & 0.256 & 0.22 & 0.245 & 0.218 \\
\hline $\begin{array}{l}\text { Office } 250 \\
\text { attorneys }\end{array}$ & 0.312 & 0.58 & 0.329 & 0.536 & 0.404 \\
\hline Public sector & 0.305 & 0.197 & 0.243 & 0.127 & 0.098 \\
\hline $\begin{array}{l}\text { Number of Jobs } \\
\text { Through Year } 5\end{array}$ & $\begin{array}{l}1.69 \\
(.83)\end{array}$ & $\begin{array}{l}1.82 \\
(.83)\end{array}$ & $\begin{array}{l}1.78 \\
(.86)\end{array}$ & $\begin{array}{l}1.89 \\
(.89)\end{array}$ & $\begin{array}{l}1.65 \\
(.82)\end{array}$ \\
\hline $\begin{array}{l}\text { Number of Jobs } \\
\text { Through Year } 15\end{array}$ & - & - & - & - & $\begin{array}{l}2.19 \\
(1.30)\end{array}$ \\
\hline $\mathrm{N}=$ & 778 & 789 & 82 & 319 & 623 \\
\hline
\end{tabular}


Table 3. Estimates of Log (Farnings) Regressions, Year 5 samples, Men*

\begin{tabular}{|c|c|c|c|c|}
\hline \multirow{2}{*}{\multicolumn{2}{|c|}{$\begin{array}{l}\text { Dependent } \\
\text { Variable }\end{array}$}} & $\mathbf{w}_{1}$ & $W_{5}$ & \multirow[b]{2}{*}{$1567)$} \\
\hline & & A. All C & Lasses $1 N=$ & \\
\hline $\begin{array}{l}\text { stdzd. } \\
\text { Beauty }\end{array}$ & $\begin{array}{l}0.0198 \\
(.0100)\end{array}$ & $\begin{array}{l}0.0131 \\
(.0079)\end{array}$ & $\begin{array}{l}0.0310 \\
(.0094)\end{array}$ & $\begin{array}{l}0.0257 \\
(.0079)\end{array}$ \\
\hline$P_{1}$ & No & Yes & No & Yes \\
\hline $\mathrm{J}_{5}$ & No & No & No & Yes \\
\hline$\overline{\mathbf{R}}^{2}$ & 0.111 & 0.231 & 0.032 & 0.349 \\
\hline & & B. $1970 \mathrm{~s}$ & Classes $(\mathrm{N}$ & $=7781$ \\
\hline $\begin{array}{l}\text { stdzd. } \\
\text { Beauty }\end{array}$ & $\begin{array}{l}0.0183 \\
(.0100)\end{array}$ & $\begin{array}{l}0.0167 \\
(.0099)\end{array}$ & $\begin{array}{l}0.0495 \\
(.0128)\end{array}$ & $\begin{array}{l}0.0431 \\
(.0114)\end{array}$ \\
\hline $\mathrm{P}_{1}$ & No & Yes & No & Yes \\
\hline$J_{5}$ & No & No & No & Yes \\
\hline$\overline{\mathbf{R}}^{2}$ & 0.022 & 0.061 & 0.020 & 0.235 \\
\hline & & C. $1980 \mathrm{~s}$ & Classes $(\mathrm{N}$ & $=7891$ \\
\hline $\begin{array}{l}\text { stdzd. } \\
\text { Beauty }\end{array}$ & $\begin{array}{l}0.0214 \\
(.0137)\end{array}$ & $\begin{array}{l}0.0053 \\
(.0116)\end{array}$ & $\begin{array}{l}0.0104 \\
(.0139)\end{array}$ & $\begin{array}{l}0.0068 \\
(.0104)\end{array}$ \\
\hline$P_{1}$ & No & Yes & No & Yes \\
\hline$J_{5}$ & No & No & No & Yes \\
\hline$\overline{\mathbf{R}}^{2}$ & 0.096 & 0.377 & 0.016 & 0.474 \\
\hline
\end{tabular}

${ }^{a}$ Each regression here and in Tables 4 and 5 also includes indicator variables for each graduating class.

${ }^{b} P_{1}$ includes: Race; type of undergraduate college; years of post BA experience before law school; whether advanced degree pre-law school; whether on a law journal; whether in courtroom competitions; unusually fast or slow completion of law school; class rank; whether held clerkship in first year; first job private; number of jobs Years 0 through 5 .

${ }^{c} J_{5}$ includes: Number of years in the private sector; vector of dummy variable for MSA size; whether in the public sector or legal aid; vector of dummy variables for number of attorneys in office. 
Table 4. Estimates of Log (Earnings) Regressions, Year 5 Samples, Women

Dependent
Variable

\begin{abstract}
stdzd.
\end{abstract}
Beauty

$\mathrm{P}_{1}$

$\mathrm{J}_{5}$

$\overline{\mathrm{R}}^{2}$

Beauty

$\mathrm{P}_{1}$

$\mathrm{J}_{5}$

$\overrightarrow{\mathrm{R}^{2}}$

$$
\text { Beauty }
$$

Stdzd.

$P_{1}$

$\mathrm{J}_{5}$

$\overrightarrow{\mathrm{R}^{2}}$ $\mathrm{w}_{1}$

$\mathbf{W}_{1}$

$W_{5}$

$\mathrm{W}_{5}$

A. All Classes $(N=401)$

$\begin{array}{clcc}0.0237 & 0.0096 & 0.0425 & 0.0138 \\ (.0157) & (.0144) & (.0220) & (.0184) \\ \text { No } & \text { Yes } & \text { No } & \text { Yes } \\ \text { No } & \text { No } & \text { No } & \text { Yes } \\ 0.153 & 0.321 & 0.043 & 0.378\end{array}$

B. 1970s Classes $(\mathrm{N}=82)$

$\begin{array}{cccc}0.0326 & 0.0143 & 0.0797 & 0.0135 \\ (.0393) & (.0445) & (.0556) & (.0613) \\ \text { No } & \text { Yes } & \text { No } & \text { Yes } \\ \text { No } & \text { No } & \text { No } & \text { Yes } \\ -0.014 & -0.0182 & -0.001 & 0.205\end{array}$

C. 1980s Classes $(\mathrm{N}=319)$

$\begin{array}{cccc}0.0219 & 0.0139 & 0.0347 & 0.0087 \\ (.0171) & (.0149) & (.0239) & (.0194) \\ \text { No } & \text { Yes } & \text { No } & \text { Yes } \\ \text { No } & \text { No } & \text { No } & \text { Yes } \\ 0.142 & 0.379 & 0.051 & 0.428\end{array}$


Table 5. Estimates of Log (Earnings) Regressions, Year 15 Samples, Men $(N=623)^{2}$

\begin{tabular}{|c|c|c|c|c|}
\hline $\begin{array}{c}\text { Dependent } \\
\text { Variable }\end{array}$ & $w_{1}$ & $w_{1}$ & $W_{5}$ & $w_{5}$ \\
\hline $\begin{array}{l}\text { stdzd. } \\
\text { Beauty }\end{array}$ & $\begin{array}{l}0.0073 \\
(.0100)\end{array}$ & $\begin{array}{l}0.0069 \\
(.0113)\end{array}$ & $\begin{array}{l}0.0442 \\
(.0135)\end{array}$ & $\begin{array}{l}0.0388 \\
(.0126)\end{array}$ \\
\hline$P_{1}$ & No & Yes & No & Yes \\
\hline $\mathrm{J}_{5}$ & No & No & No & Yes \\
\hline$\overline{\mathrm{R}}^{2}$ & 0.023 & 0.042 & 0.021 & 0.241 \\
\hline $\begin{array}{c}\text { Dependent } \\
\text { Variable }\end{array}$ & $\mathbf{W}_{15}$ & $\mathbf{w}_{15}$ & $\mathbf{w}_{15}^{b}$ & \\
\hline $\begin{array}{l}\text { stdzd. } \\
\text { Beauty }\end{array}$ & $\begin{array}{l}0.0829 \\
(.0259)\end{array}$ & $\begin{array}{l}0.0629 \\
(.0207)\end{array}$ & $\begin{array}{l}0.0542 \\
(.0202)\end{array}$ & \\
\hline $\mathrm{P}_{1}$ & No & Yes & Yes & \\
\hline$J_{5}$ & No & Yes & Yes & \\
\hline$J_{15}$ & No & Yes & Yes & \\
\hline$\overline{\mathrm{R}}^{2}$ & 0.022 & 0.413 & 0.445 & \\
\hline
\end{tabular}

${ }^{a} J_{15}$ includes: Number of year in the private sector; vector of dummy variables for MSA size; whether public sector or legal aid; vector of dummy variables for number of attorneys in office.

${ }^{b}$ Adds Year 15 annual hours to $\mathrm{J}_{15}$. 
Table 6. Effects of Beauty on Pre-Labor Market Outcomes"

Men

พomen

Classes from:
$1980 s$

1970 s

$1980 \mathrm{~s}$

Dependent

Variable:

Class Rank

3.655

(3.793)

Moot Court

$-.0144$

(.0104)

$(.0136)$

3.097

(3.706)

$-10.647$

(12.402)

3. 317

Law Journal

$$
.0016
$$

$-.0143$

$(.0167)$

$-.0065$

(.0112)

Judicial.
$-.0368$

$(.0403)$

.0436

$(.0234)$

$-.0208$

$(.0208)$

${ }^{a}$ For class rank the Table lists regression coefficients of the standardized beauty measure. For the other three dependent variables the effects of a onestandard deviation increase in the standardized ratings of beauty are presented. The regressions for class rank also include dummy variables for race, undergraduate college, pre-law school degrees, and a continuous measure of prelaw school experience. The probits for law journal and moot court include these measures and class rank, while the probit for attaining a clerkship includes these measures and all three other dependent variables listed in this Table. 
Table 7. Effects of Beauty on Attorneys' Transitions Between Sectors

Men

Women

Mean standardized Beauty

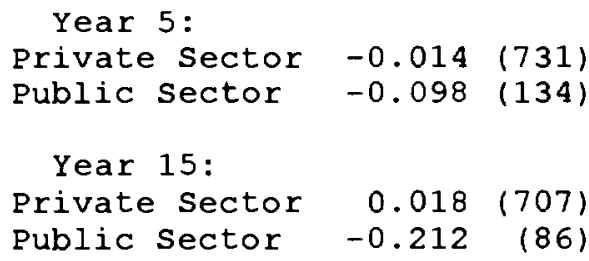

The base group contains those attorneys who practiced in the private sector in both Years 5 and 15. Each arm of the logit function also includes dummy variables for the person having been on a law journal, engaged in a court competition and tenure in a clerkship, and the continuous variable for class rank. The number of observations is included in parentheses after each mean. 
Table 8. Log (Earnings) Regressions, Year 15 Samples, Men

Private Public

\begin{tabular}{|c|c|c|c|c|}
\hline std. Dev. & $\begin{array}{l}\$ 47,642 \\
(15,270)\end{array}$ & $\begin{array}{r}\$ 122,812 \\
(81,144)\end{array}$ & $\begin{array}{l}\$ 39,926 \\
(12,026)\end{array}$ & $\begin{array}{l}\$ 49,682 \\
(12,725)\end{array}$ \\
\hline $\begin{array}{l}\text { Dependent } \\
\text { Variable }\end{array}$ & $w_{5}$ & $\mathbf{w}_{15}$ & $w_{5}$ & $\mathbf{W}_{15}$ \\
\hline $\begin{array}{l}\text { stdzd. } \\
\text { Beauty }\end{array}$ & $\begin{array}{l}0.0515 \\
(.0130)\end{array}$ & $\begin{array}{l}0.0851 \\
(.0223)\end{array}$ & $\begin{array}{l}0.0668 \\
(.0279)\end{array}$ & $\begin{array}{l}0.0636 \\
(.0356)\end{array}$ \\
\hline$\overline{\mathbf{R}}^{2}$ & 0.110 & 0.150 & 0.065 & 0.012 \\
\hline $\mathrm{N}=$ & 717 & 658 & 128 & 84 \\
\hline
\end{tabular}

${ }^{a}$ Regressions include the same variables as those in the multinomial logits in Table 7 as well as indicator variables for graduating class. 
Table 9. Effects of a One-standard Deviation Increase in standardized Beauty on the Probability of Early Partnership, 1970 s and $1980 \mathrm{~s}$ Classes*

Men

Classes:

Mean

probability:

stdzd.

Beauty

Pseudo- $\mathrm{R}^{2}$

$\mathbf{N}=$
$1970 \mathrm{~s}$

0.283

0.0587

(.0170)

.0154

$(.0080)$

.128

724
.115

761
Women

$1970 \mathrm{~s} \quad 1980 \mathrm{~s}$

0.203

0.035

$-0.0313-0.0222$

$(.0455) \quad(.0085)$

$.169 \quad .107$

$64 \quad 284$

${ }^{2}$ Each probit also includes indicator variables for the person having been on a law journal, engaged in a court competition, held a judicial clerkship, size of the law firm, and a continuous variable for class rank. 
Table 10. Mean Beauty by Specialty, 1980s Classes Year 5, 1970 s Classes Year 15

\begin{tabular}{|c|c|c|c|c|c|}
\hline & & Iitigation & Corporate & Regulation & other \\
\hline & & & and Financial & $\begin{array}{l}\text { and } \\
\text { doministrative }\end{array}$ & \\
\hline & & & Men, 1980s Cohort & Year 5 & \\
\hline Mean & Beauty & .0098 & -.0577 & -.1311 & -.0525 \\
\hline $\mathbf{N}$ & & 133 & 366 & 113 & 145 \\
\hline & & & Women, 1980s Cohor & rt Year 5 & \\
\hline Mean & Beauty & .2506 & .2169 & .0032 & .0500 \\
\hline $\mathrm{N}$ & & 56 & 126 & 46 & 57 \\
\hline & & & Men, 1970s Cohort & Year 15 & \\
\hline Mean & Beauty & .1180 & -.0295 & -.0285 & .0411 \\
\hline $\mathbf{N}$ & & 225 & 303 & 127 & 149 \\
\hline
\end{tabular}




\begin{tabular}{|c|c|c|c|c|}
\hline & & & & \\
\hline & $\begin{array}{l}1970 s \\
\text { Cohort }\end{array}$ & $\begin{array}{l}1980 \mathrm{~s} \\
\text { Cohort }\end{array}$ & $\begin{array}{l}1970 s \\
\text { Cohort }\end{array}$ & $\begin{array}{l}1980= \\
\text { Cohort }\end{array}$ \\
\hline $\mathbf{P}_{\mathbf{1}}$ & & & & \\
\hline White & $\begin{array}{l}-.0360 \\
(.0565)\end{array}$ & $\begin{array}{l}-.0206 \\
(.0374)\end{array}$ & $\begin{array}{l}-.2854 \\
(.2211)\end{array}$ & $\begin{array}{l}-.0414 \\
(.0699)\end{array}$ \\
\hline $\begin{array}{l}\text { Undergrad: } \\
\text { Same state }\end{array}$ & $\begin{array}{l}-.0063 \\
(.0310)\end{array}$ & $\begin{array}{l}-.0284 \\
(.0279)\end{array}$ & $\begin{array}{c}-.0282 \\
(.1651)\end{array}$ & $\begin{array}{l}.1090 \\
(.0641)\end{array}$ \\
\hline Ivy, 7 sisters & $\begin{array}{l}.0300 \\
(.0404)\end{array}$ & $\begin{array}{l}.0733 \\
(.0323)\end{array}$ & $\begin{array}{l}.2961 \\
(.2158)\end{array}$ & $\begin{array}{l}.1078 \\
(.0703)\end{array}$ \\
\hline Other private & $\begin{array}{l}-.0369 \\
(.0313)\end{array}$ & $\begin{array}{c}-.0173 \\
(.0264)\end{array}$ & $\begin{array}{r}-.1247 \\
(.1796)\end{array}$ & $\begin{array}{l}.0624 \\
(.0617)\end{array}$ \\
\hline $\begin{array}{c}\text { Experience pre } \\
\text { law school }\end{array}$ & $\begin{array}{l}.0030 \\
(.0066)\end{array}$ & $\begin{array}{c}-.0134 \\
(.0062)\end{array}$ & $\begin{array}{c}-.0292 \\
(.0331)\end{array}$ & $\begin{array}{c}-.0112 \\
(.0084)\end{array}$ \\
\hline M.A. & $\begin{array}{l}.0012 \\
(.0543)\end{array}$ & $\begin{array}{l}-.0007 \\
(.0418)\end{array}$ & $\begin{array}{l}-.1021 \\
(.2663)\end{array}$ & $\begin{array}{l}.0578 \\
(.0832)\end{array}$ \\
\hline Doctorate & $\begin{array}{l}.1180 \\
(.0791)\end{array}$ & $\begin{array}{l}.1575 \\
(.0078)\end{array}$ & $\begin{array}{l}.2369 \\
(.4209)\end{array}$ & $\begin{array}{l}.1421 \\
(.1641)\end{array}$ \\
\hline Law journal & $\begin{array}{l}.0651 \\
(.0304)\end{array}$ & $\begin{array}{l}.1145 \\
(.0241)\end{array}$ & $\begin{array}{l}.2257 \\
(.1619)\end{array}$ & $\begin{array}{l}.0438 \\
(.0516)\end{array}$ \\
\hline Moot court & $\begin{array}{l}.0303 \\
(.0385)\end{array}$ & $\begin{array}{l}.0023 \\
(.0272)\end{array}$ & $\begin{array}{l}.3277 \\
(.2510)\end{array}$ & $\begin{array}{l}.1002 \\
(.0559)\end{array}$ \\
\hline Finish slowly & $\begin{array}{l}-.0211 \\
(.0346)\end{array}$ & $\begin{array}{l}.0256 \\
(.0239)\end{array}$ & $\begin{array}{l}.1407 \\
(.1998)\end{array}$ & $\begin{array}{l}-.0234 \\
(.0502)\end{array}$ \\
\hline Finish fast & $\begin{array}{l}-.0366 \\
(.0411)\end{array}$ & $\begin{array}{l}.0995 \\
(.0979)\end{array}$ & $\begin{array}{l}.1372 \\
(.1808)\end{array}$ & $\begin{array}{l}.8184 \\
(.3661)\end{array}$ \\
\hline $\begin{array}{l}\text { Class rank } \\
\text { ( } 1 \text { is best) }\end{array}$ & $\begin{array}{l}-.00027 \\
(.00012)\end{array}$ & $\begin{array}{c}-.00046 \\
(.00011)\end{array}$ & $\begin{array}{l}-.00107 \\
(.00066)\end{array}$ & $\begin{array}{r}-.00014 \\
(.00024)\end{array}$ \\
\hline $\begin{array}{l}\text { Judicial } \\
\text { clerkship }\end{array}$ & $\begin{array}{l}-.0536 \\
(.0392)\end{array}$ & $\begin{array}{l}-.0262 \\
(.0326)\end{array}$ & $\begin{array}{l}-.2500 \\
(.4315)\end{array}$ & $\begin{array}{c}-.0073 \\
(.0621)\end{array}$ \\
\hline First job private & $\begin{array}{l}.1595 \\
(.0366)\end{array}$ & $\begin{array}{l}-.0314 \\
(.0425)\end{array}$ & $\begin{array}{l}.1535 \\
(.1932)\end{array}$ & $\begin{array}{l}.1333 \\
(.0793)\end{array}$ \\
\hline \# jobs years $0-5$ & $\begin{array}{l}-.0202 \\
(.0155)\end{array}$ & $\begin{array}{l}-.0420 \\
(.0131)\end{array}$ & $\begin{array}{l}.0287 \\
(.0825)\end{array}$ & $\begin{array}{l}-.0358 \\
(.0259)\end{array}$ \\
\hline
\end{tabular}


Appendix Table 1 , cont.

\begin{tabular}{|c|c|c|c|c|}
\hline Years private $0-5$ & $\begin{array}{l}.0055 \\
(.0100)\end{array}$ & $\begin{array}{l}.0387 \\
(.0112)\end{array}$ & $\begin{array}{l}.0084 \\
(.0507)\end{array}$ & $\begin{array}{l}.0114 \\
(.0211)\end{array}$ \\
\hline MSA $>1$ million & $\begin{array}{l}.2205 \\
(.0319)\end{array}$ & $\begin{array}{l}.2210 \\
(.0305)\end{array}$ & $\begin{array}{l}.5099 \\
(.1505)\end{array}$ & $\begin{array}{l}.2410 \\
(.0648)\end{array}$ \\
\hline MSA $200 \mathrm{~K}-1$ million & $\begin{array}{l}.0856 \\
(.0310)\end{array}$ & $\begin{array}{l}.0559 \\
(.0335)\end{array}$ & $\begin{array}{l}.3748 \\
(.1836)\end{array}$ & $\begin{array}{l}.0633 \\
(.0711)\end{array}$ \\
\hline $\begin{array}{l}\text { Public, legal aid } \\
\text { or other }\end{array}$ & $\begin{array}{l}.0048 \\
(.0454)\end{array}$ & $\begin{array}{l}-.2521 \\
(.0415)\end{array}$ & $\begin{array}{l}.0819 \\
(.1815)\end{array}$ & $\begin{array}{l}-.1007 \\
(.0656)\end{array}$ \\
\hline Office > 149 lawyers & $\begin{array}{l}.1876 \\
(.0895)\end{array}$ & $\begin{array}{c}.1665 \\
(.0301)\end{array}$ & $\begin{array}{l}.0073 \\
(.2731)\end{array}$ & $\begin{array}{l}.4204 \\
(.0584)\end{array}$ \\
\hline Office 50-149 lawyers & $\begin{array}{l}.0890 \\
(.0316)\end{array}$ & $\begin{array}{l}.0105 \\
(.0314)\end{array}$ & $\begin{array}{l}-.1296 \\
(.1564)\end{array}$ & $\begin{array}{l}.2928 \\
(.0631)\end{array}$ \\
\hline Office 16-49 lawyers & $\begin{array}{l}.0604 \\
(.0115)\end{array}$ & $\begin{array}{l}.0173 \\
(.0306)\end{array}$ & $\begin{array}{l}.0785 \\
(.1816)\end{array}$ & $\begin{array}{l}.1426 \\
(.0631)\end{array}$ \\
\hline
\end{tabular}




\begin{tabular}{|c|c|c|c|}
\hline White & $\begin{array}{l}-.0305 \\
(.1047)\end{array}$ & $\begin{array}{l}\text { Public, legal } \\
\text { aid or other }\end{array}$ & $\begin{array}{c}-.0784 \\
(.0887)\end{array}$ \\
\hline $\begin{array}{l}\text { Undergrad: } \\
\text { Same state }\end{array}$ & $\begin{array}{l}-.0847 \\
(.0546)\end{array}$ & office > 149 lawyers & $\begin{array}{l}.2932 \\
(.1716)\end{array}$ \\
\hline Ivy, 7 sisters & $\begin{array}{l}.0207 \\
(.0731)\end{array}$ & Office 50-149 & $\begin{array}{l}.1610 \\
(.0655)\end{array}$ \\
\hline other private & $\begin{array}{l}-.0483 \\
(.0546)\end{array}$ & $\begin{array}{c}\text { Office } 16-49 \\
J_{15}\end{array}$ & $\begin{array}{l}.1415 \\
(.0587)\end{array}$ \\
\hline $\begin{array}{l}\text { Experience pre } \\
\text { law school }\end{array}$ & $\begin{array}{l}.0062 \\
(.0120)\end{array}$ & \# jobs year 0-15 & $\begin{array}{l}.0256 \\
(.0230)\end{array}$ \\
\hline M.A. & $\begin{array}{l}.0015 \\
(.0629)\end{array}$ & Years private $0-15$ & $\begin{array}{l}.0203 \\
(.0083)\end{array}$ \\
\hline Doctorate & $\begin{array}{l}.0587 \\
(.1428)\end{array}$ & MSA > 1 million & $\begin{array}{l}.1803 \\
(.0705)\end{array}$ \\
\hline Law journal & $\begin{array}{l}.1537 \\
(.0540)\end{array}$ & MSA 200k - 1 million & $\begin{array}{l}.0278 \\
(.0671)\end{array}$ \\
\hline Moot court & $\begin{array}{l}.0814 \\
(.0687)\end{array}$ & $\begin{array}{l}\text { Public, legal aid or } \\
\text { other }\end{array}$ & $\begin{array}{l}-.2978 \\
(.0944)\end{array}$ \\
\hline Finish slowly & $\begin{array}{l}-.0248 \\
(.0610)\end{array}$ & Office > 149 lawyers & $\begin{array}{l}.3363 \\
(.0753)\end{array}$ \\
\hline Finish fast & $\begin{array}{l}-.0412 \\
(.0711)\end{array}$ & Office 50-149 lawyers & $\begin{array}{l}.1667 \\
(.0673)\end{array}$ \\
\hline $\begin{array}{l}\text { Class rank } \\
\text { ( } 1 \text { is best) }\end{array}$ & $\begin{array}{l}-.00033 \\
(.00022)\end{array}$ & Office 16-49 lawyers & $\begin{array}{l}.2452 \\
(.0602)\end{array}$ \\
\hline $\begin{array}{l}\text { Judicial } \\
\text { clerkship }\end{array}$ & $\begin{array}{l}-.0275 \\
(.0710)\end{array}$ & & \\
\hline $\begin{array}{l}\text { First job } \\
\text { private }\end{array}$ & $\begin{array}{l}.0817 \\
(.0663)\end{array}$ & & \\
\hline \# jobs years & $\begin{array}{l}-.0216 \\
(.0371)\end{array}$ & & \\
\hline $\mathbf{J}_{5}$ & & & \\
\hline $\begin{array}{r}\text { Years private } \\
0-5\end{array}$ & $\begin{array}{l}.0038 \\
(.0224)\end{array}$ & & \\
\hline MSA $>1$ million & $\begin{array}{l}.1423 \\
(.0699)\end{array}$ & & \\
\hline $\begin{array}{l}\text { MSA } 200 K-1 \\
\text { million }\end{array}$ & $\begin{array}{l}.0406 \\
(.0640)\end{array}$ & & \\
\hline
\end{tabular}

